\title{
The Impact of Management Information System on the Employees Performance Management in Sultanate of Oman Telecommunication Companies
}

\author{
Said bin Sulaiman Alhosni \\ Wade AL Hosani Trading Projects \\ E-mail: sssalhosn2005@gmail.com
}

Dr. Salman Mohammed Abu Lehyeh

Amman Arab University

Received: May 21, 2019 Accepted: June 10, 2019 Online published: July 3, 2019

doi:10.5296/ijhrs.v9i3.14789ＵRL: https://doi.org/10.5296/ijhrs.v9i3.14789

\begin{abstract}
The aim of this study is to analysis the impact of MIS on its dimensions in performance management In the Sultanate of Oman. The researcher tested the hypothesis of the study using multiple regression analysis, descriptive statistics, and Several conclusions found in the study; namely: There is an impact of management information systems on managing the performance of employees as a whole in telecommunications companies in the Sultanate of Oman. There is an impact of MIS on the performance management (performance planning) on the telecommunications companies in the Sultanate of Oman. While the results indicated that the software components and networks of management information systems do not affect the employee's performance management concerning performance planning.

There is an impact of information management systems (human resources, software, networks) on the employees' performance management represented the performance audit, and follow-up in the telecommunications companies in the Sultanate of Oman. While the results indicated that the material resources, and the MIS database did not affect the employees' performance management represented by performance review, and follow-up.

There is an impact of MIS (Human Resources, material resources, Software, Database) on the performance management of performance appraisal of telecom companies. While the results indicated that the networking component of MIS did not affect the employees' performance management represented by performance appraisal.
\end{abstract}


There is an impact of MIS on employee performance management of feedback in the telecoms companies. While the results indicated that the IT component of MIS did not affect the employees' performance management represented by feedback.

Keyword: management information system, performance management, human resources, material resources, software, database, networks, Omantel, Oredu

\section{Introduction}

Information systems provide operational, managerial and strategic support to different types of business organizations. As there is a constant and permanent need for information systems to process data left behind and used by business processes. Operations information systems produce a variety of information for both internal and external use, which can support the work of the organizations and it can be used by managers in the transactions efficiently, industrial control processes, and attribution of office communications and performance management of workers (Alrahaifa, 2017).

Human resources management relies on the processes used to identify and organize workers who, in turn, mainly constitute the total labor force at the organization level (Alkasaspa, 2011). Therefore, the human resource is considered as intellectual power, mental ability and source of information, ideas and innovations. It must be invested and employ its enormous capabilities in a positive manner, so the first objective of the management is to control the performance of human resources and ensure its compatibility in terms of methods, levels of quality and consistency with other resources, reflecting the strategic aspirations of business organizations and the requirements for its development in order to cope with modern technological developments in terms of speed, cost, and superior capacity (Laudon, et al., 2002).

The advances in the field of information technology, representing in computers, software and communication networks, have helped individuals in business organizations to develop their capacities in order to transform from the information age to the knowledge age, which has led to the emergence of many studies and researches dealing with this phenomenon (Zheng, Emma, 2013).

In a world characterized by a high degree of rapid technological development, complexity and change, as well as the enormous global challenges associated with the process of opening up to all levels towards the global markets, whereas the information has become a competitive weapon and a key resource on which the Organization's success or failure depends (Stair, et. al, 2013).

\section{Problem of the Study}

Business organizations of all kinds are facing today's world, and in an environment where a series of rapid transformations that have intensified the competition day after day are accelerating as an inevitable result of the tremendous and accelerating progress in information and communication technology of all its forms. Telecommunications companies in the Sultanate of Oman work in light of these global changes of the rise in the intensity of 
competition between companies, especially in the field of telecommunications, in addition to fierce local competition. As the telecom companies in the Sultanate of Oman are among the most affected by these factors, so there is an urgent need for these companies to work in an environment that makes them distinct in order to ensure their survival within the circle of competition and growth by improving its performance in general and the performance of its employees in particular to achieve high levels of performance management of individuals, it is noticeable that the organizations in the Sultanate of Oman may have management information systems but do not use these systems with its components to achieve its objectives efficiently and effectively. More specifically, these companies may not take into account the technical dimension of integrating management information systems and investing opportunities arising in different processes of managing the staff' performance in business organizations.

The study problem is materialize by measuring the level of use of management information systems in telecommunications companies in the Sultanate of Oman, as well as knowledge of the level of management of the performance of employees in telecommunications companies in the Sultanate of Oman, and measuring and analyzing the impact of management information systems (human resources, material resources, software, database and networks) in employees' performance management, representing in (performance planning, performance review and follow-up, performance assessment, feedback and performance improvement and development) in telecommunications companies in the Sultanate of Oman.

\section{Hypotheses of the Study}

Based on the study's default plan and its problem and the objectives it seeks to achieve, a set of main, subsidiary and statistical hypotheses has been formulated, which are considered as preliminary hypotheses, which will be tested later. These hypotheses are:

\subsection{The Main Hypothesis}

There is no statistically significant impact at the level of $(\alpha=0.05)$ for management information systems (human resources, material resources, software, database, networks) in employee performance management, representing in (performance planning, performance review and follow-up, performance assessment, feedback and Improvement and development of performance) in the telecommunications companies in the Sultanate of Oman, and from the main hypotheses, the following subsidiary hypotheses:

1. There is no statistically significant impact at the level of $(\alpha=0.05)$ for management information systems (human resources, material resources, software, database, networks) in employee performance management representing in performance planning in the telecommunications companies in the Sultanate of Oman.

2. There is no statistically significant impact at the level of $(\alpha=0.05)$ for management information systems (human resources, material resources, software, database, networks) in employee performance management representing in performance review and follow-up in the telecommunications companies in the Sultanate of Oman. 
3. There is no statistically significant impact at the level of $(\alpha=0.05)$ for management information systems (human resources, material resources, software, database, networks) in employee performance management representing in performance assessment in the telecommunications companies in in the Sultanate of Oman.

4. There is no statistically significant impact at the level of $(\alpha=0.05)$ for management information systems (human resources, material resources, software, database, networks) in employee performance management representing in feedback in telecommunications companies in the Sultanate of Oman.

5. There is no statistically significant impact at the level of $(\alpha=0.05)$ for management information systems (human resources, material resources, software, database, networks) in employee performance management representing in improving performance and development in the telecommunications companies in the Sultanate of Oman.

\subsection{Design and Methodology}

This study follows descriptive analysis to define the impact of MIS on its dimensions in performance management In the Sultanate of Oman.

\section{Theoretical Framework and Previous Studies}

\subsection{Management Information Systems}

\subsubsection{System Concept}

Before defining the general concept of the management information systems, we need to identify the concept of the system. The system is a group of interconnected and overlapped parts, which take complete or holistic forms with each other and have common objectives (Tawaaf, 2010). The system can simply be defined as a set of interconnected and interrelated elements that interact with the environment, as well as with each other to achieve an objective, either by directly accepting inputs to produce inputs by making a structured transformation (El Sakka, 2011).

Abdul Razzaq (2013) asserts that the system is "a series of interrelated elements that perform an activity, function, or work." (An-Najjar 2007) defines the system as a set of interconnected and interrelated parts that work together in an integrated and holistic manner, which have specific objectives". Murad believes that the system is a set of parts (institutions, individuals, and objects) that are interconnected, interactive, and are related to each other and designed primarily to reach the objectives as a whole.

\subsubsection{The Concept of the Information}

Hosack, et., al. (2012) asserts that "information" is the data that organize to make sense and value to the recipient. (Laudon, et., al, 2002) defines the information or as "that information that embodies data processed in the form that is meaningful to the recipient the user, and has a real value that can be adopted in the current and future decision-making process in business organizations. 
In this context, Saud (2017) asserts that there is a kind of affective relationship of information systems on information, as well as the data as it reflects the quality, and accuracy of the data included in all elements of the administrative process such as planning, organizing, guiding and control, the basis of which is to provide accurate information with certain specifications, and at times that are suitable for the beneficiaries.

\subsubsection{The Concept of the Management Information Systems}

Bussler, et al., (2012) notes that the concept of business information systems addresses the status of the flow' extent of information within a single organization and external parties (suppliers, customers, the public and the government) that improve individual performance, whether this individual is an employee or a manager, and thus improves the organization's performance.

Al-Hudhaif (2010) defined the concept as information systems used to support organization's operations and its functional fields as technological tools that collect, process, store and convert data into information in order to assist in decision-making. (O'Connor 2006) defines the concept as a group of individuals, processes, data, models, technology, and a language that work together in order to achieve the purposes of the organization's functions. (Laudon 2002) defined it as a computerized tool and software that is primarily used to support business processes in different organizations.

\subsubsection{The Importance of Information Systems}

The availability of advanced information systems reflects an effective contribution to the implementation of the organization's objectives and the associated strategies which are usually adopted to meet the ever-changing environmental conditions, especially with regard to the trends of globalization, and thus to achieve the internal and external desires of the organization in communication and innovation. The adoption of these advanced information systems represents a qualitative shift, which is different from all traditional ones (Markgraf 2013). While (Louden, et, al, 2006) Identifies, in order to ensure this trend, indicators that highlight the importance of information systems that can be summarized as follows:

1. Information systems are considered as an effective tool that contributes to the process of reducing the costs allocated for the elements of inputs (such as raw materials and labor, at rates higher than their previous rates for the organization).

2. Creating new opportunities for offering new products and services, such as expert systems as well as decision support systems that have not been seen before in the organization.

3. Improve the service provided to the customer by meeting his or her requests and desires through terminals.

Abbas (2014) asserted that information technology has an important role to play in managing changes in the organization and in accordance with the following frameworks:

1. Support the aspects of the effectiveness of the manager and prepare the systematic means in order to be applied in normal circumstances and to lead the process of renewal as well. 
2. Give managers important opportunities to analyze, handle and realize a large amount of data and the formulas of its process for later use.

3. To increase the capacity of the two managers in order to carry out the aspects of innovation and development with more accurately and more rapidly than before in order to prepare for the practical change in the Organization.

\subsubsection{Objectives of Management Information Systems}

One of the objectives of management information systems is the possibility of eliminating the traditional work that leads to increase the administrative standard and accuracy as well, in line with the new aspects of the flow of the information, and the advantages offered by the use of information technology but has not yet been fully invested by transferring it among all administrative units, reducing data collection efforts and designing an information system that meets the needs of all departments in order to achieve an increase in the productivity and improve the quality of administrative operations (Abdul Razzaq 2013).

Stair et al., (2013) in identifying in his study referred to the effects of the use of management information systems in businesses' organizations and the diagnosis of its objectives by the following:

1. The information systems seek to carry out essential aspects in order to introduce all new products that are appropriate to the nature of the developments in the markets, which have a clear impact on the work of the employees and the achievement of job satisfaction.

2. Activate the functions and aspects of the internal control inside the organizations.

3. Provide and organize the necessary information in order to support all programs that enhance the relationships between the daily operations and investments to ensure the appropriate strategies and the responsibilities arising from such investments.

\subsubsection{Components of Business Information Systems}

In order for information systems to perform its core functions and activities (inputs, processes, outputs and feedback), there must be a set of components, means or resources to enable them to perform these functions (Markgraf 2013). The views of the thinkers and researchers specialized in the field of information systems differ in the components of these systems, means and resources that enable them to perform the functions of these basic systems (Stair et al., 2013). However, it is necessary to present these components and how to analyze them whereas the current study depends on these components as basic dimensions in the independent variable in this (O'Brien 2011), and (Al-Hudhaif 2010).

First: Technical specialist' individuals

They are the individuals who work on the development of information systems. This group includes systems analysts, programmers and computer operators. They can also be called users; they are a group of individuals who use different information systems in order to obtain results and outputs of material value for the organization. 
Second: the physical components

Physical components include all hardware, tools and materials that the organizations use in the processing information. The physical components are divides into two important parts:

a- Computers' systems: Electronic computers and its associated physical parts, which are always in direct contact with the data, update the stored information, address the stored information and output the possible results (Markgraf (2013).

b- Terminal components:

These are accessories that are connected to computers and help users to get the work done easily, such as the keyboard, mouse, video monitors, display, magnetic disks that are used to store information, special pens for data entry, commands, etc. (Sahu,et al., 2016).

Third: Software

A set of commands, instructions directed to the computer to address Input: data input stored in the computer to extract results, these results are the outputs in order to achieve, the objectives set by management. There are many types of software, such as systems' software, applications' software, and end-user software (Brown 2010).

Fourth: Databases

It is a set of structured data that can be updated easily periodically and that is possible to access to its contents, as well as that they are restrictions or records are referred to as file and usually it may consist of database of one file or more (Al-Tit 2016).

Fifth: Networks

The concept of networks, which is considered as the main component of all information systems, as remote communication, communication technology by using internet and additional networks (Extranet) used in organizations, has become a key factor for the success of these organizations (O'Brien 2011).

\subsection{Performance Management}

In the most recent years, many organization moved toward using the concept of performance management which is deemed more efficient, where the employees in all sites from the lowest level to the increasingly busy managers, who have more requirements, so the key to achieve success is working more efficiently (Torrington, et. al, 2014).

From this point, Performance management process is characterized as it is working on development and improvement continuously. It also deals with the behaviors of employees to ensure follow up and occupational conduct. Performance management also includes the activities, which enable achievement of purposes continually and efficiently. In addition, performance Management is deemed as a process performed by the organization to harmonize its resources, systems, and employees, together with the purposes and strategic priorities (Aktham, et., al. 2010) (frolick, et., al, 2006). 


\subsubsection{Performance Management Concept}

In recent years, many organizations have begun to use the concept of performance management, which is most effective as it is a system, which goes beyond bureaucracy and politics. It focuses on the most important element, which is the personnel in the organization. If the personnel knew what is expected and realized that they control their success, and understand their role in the success of the organization, they will have the incentive that, helps them to enhance productivity and profitability. (Armstrong, 2006).

The general concept of performance management is characterized by many difficulties and distortions, especially in the process of precise identification due to the diversity and variety of approaches and outputs in research and analysis as well as the diversity of intellectual attitudes among researchers and writers. The concept of management is very broad with various dimensions, with inclusive limit. As it is deemed a main method to improve and increase performance. Such that we cannot measure and determine performance management except by addressing the performance clearly and obviously, in accordance with the standards that govern the performance of the results achieved by the individual to meet specific goals or develop the competencies, which are necessary to do work effectively Desler (2015).

(Noe, et. al, 2018) also defined it as a continuous operation for common work done by managers and employees, including: Identifying the expectations of performance with connected to the objectives at the level of Organization renew the main standards, measure the performance of individual and organization. Determine the fields, which may enhance the efficiency of work provide the feedback of performance, assign and approve the continuous review to measure the actual performance of individuals inside the organization.

\subsubsection{Performance Management Processes}

Performance management is a complex, integrated process consists of several processes that systematically aim to reach certain results and ensure them to the personnel involved in the targeted performance process and in relation to the goals and objectives of the organization in an integrated manner. Researchers and writers differ in diagnosing the basic processes that would include the process of performance management obviously (Al-Tit et., al, 2016) and (lliyan 2015). The performance Management Process include some processes which are (Directing performance process, performance improvement process, performance development process, Performance diagnosing process, and performance planning process (Armstrong 2006):

\section{Performance planning}

It is one of the main functions in the modern management, it deemed important as it works on achieving the development of the organizations' objectives continuously as it works on planning the use of human resources and the rare ones in the society, as it works on achieving the highest degree of satisfaction.

Implementation of performance and directing thereof

It refers to the way the organization uses the organizational structure as well as the 


\section{Macrothink}

International Journal of Human Resource Studies

ISSN 2162-3058 2019, Vol. 9, No. 3

controlling systems. In addition to the culture of adopting the strategies which drive the excellent performance in the organization.

Follow up performance and assessment

This is performed in order to control and follow up the actual performance in the organization to justify and remedy the reasons of deficiency in performance, which may improve the outputs and objectives of the organization.

Improvement of performance and development

The performance improvement processes are based on the direct treatment, where there is a direction toward the development and creativity process and edit new objectives, which do not exist (Al-Sarayreh et., al, 2016).

\section{Approach of Study}

The study will depend on testing its hypotheses through the analytical descriptive statistical approach, by studying the relationship of impact between the variables of study from the companies (sample of study).

\section{Community of Study}

It work in Telecommunications Sector in Sultanate of Oman, two of them are officially registered, they are Omantel Company, where (4000) employees work, and Ooredoo Telecommunications company where (1010) employees work, i.e. (5010) employees in both companies. The number of employees in senior and medium management is (554) male and female employees.

\section{Sample of Study}

Sample of Study selected and their number is (227) employees work in the medium and senior management as inspecting unit, according to the table of sample size, which is extracted from the size of society provided in (Sekaran et., al, (2012).

The research depended on stratified random sample method to take a sample from the community of study, which is deemed probabilistic sampling accepted scientifically, to consider the administrative positions in selecting sample (Senior and Medium Management). Questionnaires are distributed to the study sample of which number is (227), and all of them responded thereto.

\section{Findings}

8.1 Field Study Results of Measurement the Level of Using Administrative Information Systems in Telecommunications companies in Sultanate of Oman

Arithmetic average and standard deviation and arrange the responses of the sample of study according to the dimensions of the administrative information systems in the study questionnaire generally, then each dimension of the five dimensions in the administrative information systems are detailed. The results are as follows: 
Table 1 shows the Arithmetic average and the standard deviations, as well as the order of the responses of the sample of study according to the dimensions of the administrative information systems generally.

Table (1). Arithmetic average and the standard deviations, as well as the order of the responses of the study sample according to the dimensions of the administrative information systems generally

\begin{tabular}{l|l|c|c|c}
\hline \multicolumn{1}{c|}{ Order } & \multicolumn{1}{|c|}{$\begin{array}{c}\text { Administrative information systems } \\
\text { dimensions }\end{array}$} & $\begin{array}{c}\text { Arithmetic } \\
\text { average }\end{array}$ & $\begin{array}{c}\text { Standard } \\
\text { deviations }\end{array}$ & Level of usage \\
\hline 1. & Physical resources & 4.32. & 0.55. & High \\
\hline 2. & Software & 4.30. & 0.58. & High \\
\hline 3. & Database & 4.13. & 0.50. & High \\
\hline 4. & Networks & 4.10. & 0.55. & High \\
\hline 5. & Human Resources & 3.95. & 0.67. & High \\
\hline- & Whole Administrative Information Systems & 4.14. & 0.51. & High \\
\hline
\end{tabular}

The results provided in table 1 shows that the level of using the whole administrative information systems in the telecommunications companies in Sultanate of Oman is high. The arithmetic average for the responses of sample on the dimensions as a whole is 4.14 with standard deviation 0.51

\subsection{Field Study Results of Measurement of the Level of Using Employees' Performance Management Level in Telecommunications Companies in Sultanate of Oman}

Arithmetic average and standard deviation and arrange the responses of the sample of study according to the dimensions of the administrative information systems in the study questionnaire generally, then each dimension of the five dimensions in the administrative information systems are detailed. The results are as follows:

Table 2 shows the Arithmetic average and the standard deviations, as well as the order of the responses of the sample of study according to the dimensions of the administrative information systems generally.

Table (2) shows the Arithmetic average and the standard deviations, as well as the order of the responses of the sample of study according to the dimensions of the administrative information systems generally,

\begin{tabular}{l|l|l|l|l}
\hline Order & Performance Management dimensions & $\begin{array}{l}\text { Arithmetic } \\
\text { average }\end{array}$ & $\begin{array}{l}\text { Standard } \\
\text { deviations }\end{array}$ & Level \\
\hline 1. & $\begin{array}{l}\text { Improvement and development of } \\
\text { performance }\end{array}$ & 4.14. & 0.63. & High \\
\hline 2. & Feedback & 4.00. & 0.68. & High \\
\hline 3. & Performance assessment & 3.98. & 0.58. & High \\
\hline 4. & Performance planning & 3.91. & 0.64. & High \\
\hline 5. & Review and follow up performance & 3.89. & 0.53. & High \\
\hline- & Performance Management (wholly) & 4.01. & 0.55. & High \\
\hline
\end{tabular}

The results provided in table 2 shows that the level of using the whole administrative 
information systems in the telecommunications companies in Sultanate of Oman is high. The arithmetic average for the responses of sample on the dimensions as a whole is 4.01 with standard deviation 0.55

\subsection{Results of Testing the Hypothesis of Study}

To ensure that the date are appropriate to the hypothesis of deviation analysis, the researcher made some tests to ensure that there is no high multicollinearity between the independent variable dimensions using testing Variance inflation factor with taking into consideration that the variance inflation factors shall not exceed the value, with testing the variance tolerance. Such that the variance tolerance shall be more than 0.05 in addition to ensuring that the data follows up the normal distribution through calculating the Skewness factor, and taking into consideration that the skewness factor is confined between +1 and -1 . Table 3 shows the results.

Table (3). Testing the Variance Inflation Factor, Tolerance and Skewness for the independent variable dimensions

\begin{tabular}{l|l|l|l}
\hline Independent variable dimensions & Tolerance & VIF & Skewness \\
\hline Human Resources & 0.285. & 3.506. & -0.056. \\
\hline Physical resources & 0.227. & 4.396. & -0.753. \\
\hline Software & 0.176. & 5.683. & -0.848. \\
\hline Database & 0.386. & 2.592. & -0.531. \\
\hline Networks & 0.337. & 2.963. & -0.572. \\
\hline
\end{tabular}

The data in table 3 shows that the values of testing tolerance ranged between $(-0.176$ and 0.386 ) and it is more than 0.05 . This shows that there is no high connection between the Multicollinearity independent variable dimensions. The values of testing VIF for all variables are less than 10. The data for the normal distribution were determined by calculating the skewness factor. Its values ranged between -0.056 and -0.848 . This indicates that the data applies the normal distribution system.

\subsubsection{Results Related to the Main Hypothesis}

To make a test on this hypothesis, the multiple regression analysis used to measure the effect of the independent variable (MIS) in its five dimensions (human resources, material resources, software, database, networks) in the dependent variable (DMS) as a whole. The validity of the model for this hypothesis was verified by extracting the results of the regression analysis as shown in Table (4).

Table (4). Results of Analysis of Variance to verify the validity of the model to test the main hypothesis

\begin{tabular}{l|c|c|c|c|c|c|c}
\hline $\begin{array}{c}\text { Source of } \\
\text { variation }\end{array}$ & $\begin{array}{c}\text { Total } \\
\text { squares }\end{array}$ & $\begin{array}{c}\text { Degrees } \\
\text { of } \\
\text { freedom }\end{array}$ & $\begin{array}{c}\text { Average } \\
\text { of } \\
\text { squares }\end{array}$ & $\begin{array}{c}\text { calculated } \\
\text { F value }\end{array}$ & $\begin{array}{c}\text { Level of } \\
\text { significance }\end{array}$ & $\begin{array}{c}\text { Correlation } \\
\text { coefficient R }\end{array}$ & $\begin{array}{c}\text { Coefficient of } \\
\text { determination R2 }\end{array}$ \\
\hline Regression & 61.262 & 5 & 12.252 & 356.601 & $* 0.000$ & 0.943 & 0.890 \\
\hline The error & 7.593 & 221 & 0.034 & & & & \\
\hline Total & 68.856 & 226 & & & & & \\
\hline
\end{tabular}


* Statistical level at $(0.05 \alpha)$

Table (4) shows the validity of the model to test the main hypothesis. The data show that the calculated value of $(F)$ of the model (356.601) is a statistical value at $(\alpha 0.05)$. The value of the (R2) the independent variables in the model explain $(89 \%)$ of the variance in the dependent variable (PER). Table (5) shows the results of the main hypothesis test using multiple regression analysis.

Table (5). Results of Multiple Regression Analysis to Examine the Impact of Management Information Systems in its Five Dimensions, in Managing the Performance of Employees as a Whole in Telecommunications Companies in the Sultanate of Oman

\begin{tabular}{l|c|c|c|c|c}
\hline $\begin{array}{l}\text { Independent variable } \\
\text { (Administrative } \\
\text { information system) }\end{array}$ & $\begin{array}{c}\text { B } \\
\text { Size of the effect }\end{array}$ & $\begin{array}{c}\text { Standard } \\
\text { error }\end{array}$ & Beta & $\begin{array}{c}\text { Calculated t } \\
\text { value }\end{array}$ & $\begin{array}{c}\text { Level of } \\
\text { significance }\end{array}$ \\
\hline Constant (Constant) & -.0208 & 0.111 & & -1.874 & 0.062 \\
\hline Human Resources & 0.266 & 0.035 & 0.322 & 7.699 & $* 0.000$ \\
\hline Physical resources & 0.221 & 0.047 & 0.219 & 4.668 & $* 0.000$ \\
\hline Software & 0.175 & 0.051 & 0.183 & 3.434 & $* 0.001$ \\
\hline Database & 0.224 & 0.040 & 0.202 & 5.618 & $* 0.000$ \\
\hline Networks & 0.130 & 0.039 & 0.130 & 3.372 & 0.0001 \\
\hline
\end{tabular}

* Statistical level at $(0.05 \alpha)$

The results in Table (5) show that the most significant dimensions of management information systems have an impact on the management of the performance of employees as a whole after human resources. The calculated value of (7.699) and Beta (0.322) The value of the (B) "impact size" (0.266) indicates the improvement in the dependent variable (the management of the performance of employees as a whole) as a result of the increase in the use of human resources, ie, the increase in the use of human resources in the value of one unit improves the management of the performance of employees as a whole (26.6\%) of this unit. Followed by the effect after the database, where the value of $(t)$ calculated (5.618) and the value (Beta) (0.202) and statistical significance (0.05 $\alpha \alpha)$, and the value of (B) of (0.224) we conclude that the increase in the use of the database The value of one unit improves the performance management of employees as a whole by $(22.4 \%)$ of this unit. The value of $(t)$ calculated for (4.668) and the value of (Beta) (0.219) and the statistical significance $(0.05 \alpha$ $\alpha)$, and the value of (B) of $(0.221)$ We conclude that the increase in the use of material resources in the value of one unit improves the performance management of employees as a whole by $(22.1 \%)$ of this unit

The fourth factor in terms of impact on the performance management of employees as a whole, the value of (t) calculated (3.434) and the value of (Beta) (0.183) and statistical significance $(0.05 \alpha \alpha)$, and the value of (B) of (0.175) The increase in software usage by one unit improves employee performance management by $17.5 \%$ of this unit. Finally, after the networks in terms of impact, the value of (t) calculated (3.372) and the value (Beta) (0.130) and statistical significance $(0.05 \alpha \alpha)$, and the value of (B) and the $(0.130)$ we conclude that 
the increase in the use of networks value One unit improves employee performance management by $13 \%$ of this unit.

Based on the above, the main hypothesis was rejected as follows: There is a statistically significant positive effect at the level $(\alpha=0.05)$ of the MIS (human resources, material resources, software, database, networks) in managing the performance of workers in their dimensions as a whole. Telecommunications companies in the Sultanate of Oman.

\subsubsection{Results for the First Sub-Hypothesis}

To test this hypothesis has been used multiple regression to measure the impact of the independent variable analysis test (management information systems) five dimensions (human resources, material resources, software, database, networks) in the dependent variable (Performance Planning) as employee performance management dimensions. The validity of the model for this hypothesis was verified by extracting the results of the regression analysis as shown in Table (6).

Table (6). Results of Analysis of Variance to verify the validity of the model to test the first hypothesis

\begin{tabular}{l|c|c|c|c|c|c|c}
\hline $\begin{array}{l}\text { Source of } \\
\text { variation }\end{array}$ & $\begin{array}{l}\text { Total } \\
\text { squares }\end{array}$ & $\begin{array}{l}\text { Degrees of } \\
\text { freedom }\end{array}$ & $\begin{array}{l}\text { Average } \\
\text { of } \\
\text { squares }\end{array}$ & $\begin{array}{l}\text { calculated } \\
\text { F value }\end{array}$ & $\begin{array}{l}\text { Level of } \\
\text { significance }\end{array}$ & $\begin{array}{c}\text { Correlation } \\
\text { coefficient } \\
\mathrm{R}\end{array}$ & $\begin{array}{c}\text { Coefficient of } \\
\text { determination } \\
\mathrm{R}^{2}\end{array}$ \\
\cline { 1 - 5 } Regression & 56.757 & 5 & 11.351 & 71.497 & $0.000^{*}$ & 0.786 & 0.618 \\
\cline { 1 - 4 } error & 35.088 & 221 & 0.159 & & & & \\
\cline { 1 - 4 } Total & 91.844 & 226 & & & & & \\
\hline
\end{tabular}

* Statistical level at $(0.05 \alpha)$

Table (6) shows the validity of the model to test the first hypothesis. The data show that the calculated value of $F$ (71.497) $(61.8 \%)$ of variance in the dependent variable (performance planning) as one of the dimensions of employee performance management. Table (24) shows the results of the first sub-hypothesis test using multiple regression analysis.

\subsubsection{Results Related to the Second Sub-Hypothesis}

To test this hypothesis has been used multiple regression to measure the impact of the independent variable analysis test (management information systems) five dimensions (human resources, material resources, software, database, networks) in the dependent variable (performance review and follow-up) as employee performance management dimensions. The validity of the model for this hypothesis was determined by extracting the results of the regression analysis as shown in Table (7). 
Table (7). Results of (AOV) to verify the validity of the model to test the second hypothesis

\begin{tabular}{l|l|l|l|l|l|l|l}
\hline $\begin{array}{l}\text { Source of } \\
\text { variation }\end{array}$ & $\begin{array}{l}\text { Total } \\
\text { squares }\end{array}$ & $\begin{array}{l}\text { Degrees } \\
\text { of } \\
\text { freedom }\end{array}$ & $\begin{array}{l}\text { Average } \\
\text { of } \\
\text { squares }\end{array}$ & $\begin{array}{l}\text { calculated } \\
\text { F value }\end{array}$ & $\begin{array}{l}\text { Level of } \\
\text { significance }\end{array}$ & $\begin{array}{l}\text { Correlation } \\
\text { coefficient } \\
\mathrm{R}\end{array}$ & $\begin{array}{l}\text { Coefficient of } \\
\text { determination } \\
\mathrm{R}^{2}\end{array}$ \\
\hline Regression & 38.685 & 5 & 7.737 & 69.029 & $0.000^{*}$ & 0.781 & 0.610 \\
\hline error & 24.771 & 221 & 0.112 & & & & \\
\hline Total & 63.456 & 226 & & & &
\end{tabular}

* Statistical level at $(0.05 \alpha)$

Table (7 shows) validity of the model to test the second sub-hypothesis, where data show, that the value (F) calculated for the model (69.029), which is statistically significant at the level of value $(0.05 \geq \alpha)$, has reached the value of the coefficient of determination (R2) (0.610) (61) of the variance in the dependent variable (performance review and follow-up) as one of the dimensions of employee performance management. Table (26) shows the results of the second sub-hypothesis test using multiple regression analysis.

\subsubsection{Results Related to the Third Sub-Hypothesis}

To test this hypothesis has been used multiple regression to measure the impact of the independent variable analysis test (management information systems) five dimensions (human resources, material resources, software, database, networks) in the dependent variable (performance) evaluation of employee performance management as one of the dimensions. The validity of the model for this hypothesis was verified by extracting the results of the regression analysis as shown in Table (8).

Table (8) indicates the validity of the model to test the third hypothesis. The data show that the calculated value of $(\mathrm{F})$ of the model (122.906) is a statistically significant value at $\alpha$ (0.05). The value of the R2 (0.735) (73.5\%) of variance in the dependent variable (performance evaluation) as one of the dimensions of employee performance management. Table (28) shows the results of the third sub-hypothesis test using multiple regression analysis.

Table (8). Results of Analysis of Variance to verify the validity of the model to test the third hypothesis

\begin{tabular}{l|l|l|l|l|l|l|l}
\hline $\begin{array}{l}\text { Source of } \\
\text { variation }\end{array}$ & $\begin{array}{l}\text { Total } \\
\text { squares }\end{array}$ & $\begin{array}{l}\text { Degrees } \\
\text { of } \\
\text { freedom }\end{array}$ & $\begin{array}{l}\text { Average } \\
\text { of } \\
\text { squares }\end{array}$ & $\begin{array}{l}\text { calculated } \\
\text { F value }\end{array}$ & $\begin{array}{l}\text { Level of } \\
\text { significance }\end{array}$ & $\begin{array}{l}\text { Correlation } \\
\text { coefficient } \\
\mathrm{R}\end{array}$ & $\begin{array}{l}\text { Coefficient of } \\
\text { determination } \\
\mathrm{R}^{2}\end{array}$ \\
\hline Regression & 56.317 & 5 & 11.263 & 122.906 & $0.000^{*}$ & 0.858 & 0.735 \\
\hline error & 20.253 & 221 & 0.092 & & & & \\
\hline Total & 76.570 & 226 & & & & \\
\hline
\end{tabular}

* Statistical level at $(0.05 \alpha)$ 


\subsubsection{Results Related to the Fourth Sub-Hypothesis}

To test this hypothesis, the multiple regression analysis was used to measure the effect of the independent variable (MIS) in its five dimensions (human resources, material resources, software, database, networks) in the dependent variable as a dimension of employee performance management. The validity of the model for this hypothesis was verified by extracting the results of the regression analysis as shown in Table (9).

Table (9). Analysis of Variance results to confirm the validity of the model to test the fourth hypothesis

\begin{tabular}{l|l|l|l|l|l|l|l}
\hline $\begin{array}{l}\text { Source of } \\
\text { variation }\end{array}$ & $\begin{array}{c}\text { Total } \\
\text { squares }\end{array}$ & $\begin{array}{c}\text { Degrees } \\
\text { of } \\
\text { freedom }\end{array}$ & $\begin{array}{c}\text { Average } \\
\text { of } \\
\text { squares }\end{array}$ & $\begin{array}{c}\text { calculated } \\
\text { F value }\end{array}$ & $\begin{array}{c}\text { Level of } \\
\text { significance }\end{array}$ & $\begin{array}{c}\text { Correlation } \\
\text { coefficient } \\
\mathrm{R}\end{array}$ & $\mathrm{R}^{2}$ \\
\hline Regression & 87.889 & 5 & 17.578 & 245.896 & $0.000 *$ & 0.921 & 0.848 \\
\cline { 1 - 4 } error & 15.798 & 221 & 0.071 & & & & \\
\hline Total & 103.687 & 226 & & & & & \\
\hline
\end{tabular}

* Statistical level at $(0.05 \alpha)$

The table indicates (9) to the validity of the model to test the sub-hypothesis fourth, where the data show, that the value (F) calculated for the model (245.896), which is statistically significant at the level of value $(0.05 \geq \alpha)$, has reached the value of the coefficient of determination (R2) $(0.848(84.8 \%)$ of variance in the dependent variable as one of the dimensions of employee performance management. Table (30) shows the results of the fourth sub-hypothesis test using multiple regression analysis.

\subsubsection{Results Related to the Fifth Sub-Hypothesis}

To test this hypothesis, the multiple regression analysis was used to measure the impact of the independent variable (MIS) in its five dimensions (human resources, material resources, software, database, networks) in the dependent variable (performance improvement and development). The validity of the model for this hypothesis was verified by extracting the results of the regression analysis as shown in Table (10).

Table (10). Results of the Analysis of Variance analysis to verify the validity of the model to test the fifth hypothesis

\begin{tabular}{l|l|l|l|l|l|l|l}
\hline $\begin{array}{l}\text { Source of } \\
\text { variation }\end{array}$ & $\begin{array}{c}\text { Total } \\
\text { squares }\end{array}$ & $\begin{array}{c}\text { Degrees } \\
\text { of } \\
\text { freedom }\end{array}$ & $\begin{array}{c}\text { Average } \\
\text { of } \\
\text { squares }\end{array}$ & $\begin{array}{c}\text { calculated } \\
\text { F value }\end{array}$ & $\begin{array}{c}\text { Level of } \\
\text { significance }\end{array}$ & $\begin{array}{c}\text { Correlation } \\
\text { coefficient } \\
\mathrm{R}\end{array}$ & $\mathrm{R}^{2}$ \\
\hline Regression & 66.417 & 5 & 13.283 & 127.746 & $0.000^{*}$ & 0.862 & 0.743 \\
\hline error & 22.980 & 221 & 0.104 & & & & \\
\hline Total & 89.397 & 226 & & & & \\
\hline
\end{tabular}

* Statistically significant at the level $(0.05 \geq \alpha)$

The table indicates (10) to the validity of the model to test the sub-hypothesis fifth, where data show, that the value (F) calculated for the model (127.746), which is statistically 
significant at the level of value $(0.05 \geq \alpha)$, has reached the value of the coefficient of determination (R2) (0.743) in the sense that the independent variables in the model explain the percentage of $(74.3 \%)$ of the variation in the dependent variable (performance improvement and development) as one of the dimensions of employee performance management, and shows the table (32) test results of the fifth sub-hypothesis by using multiple regression analysis.

\section{Discussion of Findings}

This chapter discusses the findings of the study and links them to previous studies, and presents the recommendations and proposals, which were drawn in light of the results of the study:

1. The results of the field study showed that the level of use of MIS in Oman's telecom companies came from all five dimensions of the five MISs with high level of use.

2. The results of the field study showed that the performance of workers as a whole in telecommunications companies in Oman, the management level came all the paragraphs of the performance of the five dimensions of management personnel at a high level. These high results can be attributed to the application of modern methods in the development of human resources, including performance appraisal management systems.

3. The main hypothesis of the study rejected. The results showed that there is an impact of management information systems (human resources, material resources, software, database, networks) in managing the performance of the employees as a whole in the telecommunications companies in the Sultanate of Oman. The most significant dimensions of management information systems have an impact on the management of employee performance as a whole, after human resources, followed by impact after the database. Material resources came third in terms of impact on the performance management of employees as a whole. As a whole, finally came after the networks in terms of impact. This indicates that the management information systems used by telecommunications companies in the Sultanate of Oman have an important and effective role in providing managers with the necessary and necessary information in the process of managing the performance of employees, and that the employees at the senior and middle management levels in these companies are fully convinced of the importance of management information systems In facilitating the process of evaluating the performance of employees in Omani telecom companies.

3. The first sub-hypothesis rejected partially because the results showed that there is an impact of the MIS (Human Resources, Physical Resources, Database) in the performance management of performance planning in the telecommunications companies in the Sultanate of Oman. The most significant dimension of IMIS has been found to be material resources, followed by impact on human resources, followed by a third in terms of impact on performance planning, while results show that both software and networks from MIS do not affect Performance Planning in Employee Performance Management.

5. The second sub-hypothesis rejected partially. The results showed that there is an impact of 
MIS (Human Resources, Software, Networks) in the performance management of performance audit and follow-up in the telecommunications companies in the Sultanate of Oman. The most significant dimension of management information systems in performance review and follow-up has been found to be human resources In the impact after the software, followed by networks third in terms of impact on performance review and follow-up, while the results showed that the physical resources and information base of the MIS do not affect the performance audit and follow-up in the performance management of employees in the management of staff performance

6. The third sub-hypothesis rejected partially. The results showed that there is an impact of MIS (Human Resources, Physical Resources, Software, Database) in the performance management of the performance evaluation of the telecoms companies in the Sultanate of Oman. It was found that the most significant dimensions of the MIS in performance evaluation is after the database, followed by the impact after the software, the human resource dimension came third in terms of the impact on the performance evaluation, the material resources came forth in terms of impact on the performance evaluation. The results that after networks of MIS does not affect the performance evaluation in the performance management of employees,

7. The fourth sub-hypothesis rejected partially. The results showed that there is an impact of the MIS (human resources, material resources, database, and networks) in the management of employee performance of feedback in the telecommunications companies in Oman. It was found that the most important dimension of management information systems has an impact on human resources, followed by impact after material resources, followed by a third in terms of impact on feedback, followed by networks in terms of impact on feedback, The results that after the software of MIS does not affect the feedback in the performance management of employees.

8. The fifth sub-hypothesis partially rejected, where the results showed that there is an impact of the MIS (Human Resources, Physical Resources, Database, Networks) in the performance management of employees in improving the performance and development in the telecommunications companies in Oman, It turns out that the more dimensions of management information systems impact on improving performance and scalability is after human resources, followed by the impact after networks after material resources III in terms of impact, The fourth was in terms of the impact on performance improvement and development, while the results showed that after the software from the MIS does not affect the performance improvement and development in the performance management of employees.

\section{The Recommendations}

Depending on the results of the study, it has been out a set of recommendations and suggestions, as follows:

1. Based on the results that showed that the two components of software and networks of MIS do not affect the performance planning of the performance management of employees in telecommunications companies in the Sultanate of Oman. The researcher 
recommends that companies employ software, and networks in ways that contribute to the achievement of performance planning effectively.

2. Based on the results that showed that the material resources and information base of MIS do not affect the performance audit and follow-up of the performance management of employees in telecommunications companies in the Sultanate of Oman. The researcher recommends that companies reconsider how the employ material resources and information based on performance review and follow-up process.

3. Based on the results that showed that the networking component of management information systems does not affect the performance evaluation of the performance management of employees in telecommunications companies in the Sultanate of Oman. The researcher recommends that companies reconsider how the networks employ in the performance appraisal process.

4. Based on the results that showed that the software component of the MIS does not affect the feedback from the performance management of employees in telecommunications companies in the Sultanate of Oman. The researcher recommends that those companies work to provide software that can contribute to the provision of appropriate to the process of performance of employees in those companies management feedback.

\section{References}

Abbas, J., Muzaffar, A., \& Mohammad, H. (2014). Impact of technology on performance of employees (Case Study on Allied Banks LTD Pakistan). World Applied Sciences Journal, 29(2).

AbdulRazzaq, A. (2013). Information management systems. I. Cairo: Horus International Foundation for Publishing and Distribution.

Aktham, Al-S., \& Ruwaida, G. (2010). The Role of Human Resource Management in Organizational Creativity as Seen by Jordan Telecom Company Workers: A Case Study, Jordanian Journal of Business Administration, 6(7).

Al-Hudhaif, S. (2010). Measuring Quality of Information System Services in Manufacturing Organizations in Riyadh. JKAU: Econ. \& Adm., 24(1). https://doi.org/10.4197/Eco.24-1.4

Alkasaspa, M. (2011). Improve the efficiency of corporate performance through IT. Amman: Dar Al Yazouri Publishing and Distribution.

Alrahaifa, T. (2017). The impact of human resources information system elements in rationalizing human resources management decisions in the Customs Department. Unpublished Master Thesis, Amman Arab University, Amman, Jordan.

Al-Sarayreh, A., \& Naila, M. Al-H. (2016). The Impact of Human Resources Auditing on the Application of Governance in the Banking Sector in Jordan Macrothink Journal of Human Resource Management. Canada, 5.

Al-Tit, A. A. (2016). The Mediating Role of Knowledge Management and the Mode Part of Organizational Culture between HRM Practices and Organizational Performance. International Business Research journal, 9(1). https://doi.org/10.5539/ibr.v9n1p43

Al-Tit, A. A. (2016).Mamgement Information System in Public Institution in Jordan. An Eye on Implementation Success Factors and Their Relationship with Organizational Performance International Journal of Advanced Computer and Applications, 7(7), 457-463. 
An-Najjar, F. (2007). Management Information System. I.2. Oman: Dar Al-Hamed Publishing and Distribution.

Armstrong, M. (2006). Performance Management. Third Edition. London: Practical Guidelines.

Armstrong, M., \& Taylor, S. (2014). Human Resource Management. Armstrong's Handbook USA: Practice Hall.

Brown, D. (2010). An Experiential Approach to Organization development. Eighth Edition. N. $\mathrm{J}$ : Pearson education Inc.

Bussler, L., \& Daivis, E. (2012). Information System: The Quiet Revolution in Human Resource Management. Journal of Computer Information System, 42(2).

Desler, G. (2015). Human Resource Management, Translation and Localization by Mohamed Sayed Abdel Muttal. Riyadh: Dar Al-Marikh for publishing. https://doi.org/10.1201/1078.10580530/45769.23.1.20061201/91771.5

El Sakka, Z. (2011). Accounting Information System. I. Mosul: Dar Al-Tarek Publishing and Distribution.

Frolick, M., \& Ariychandra, T. (2006). Business Performance Management. One Truth, College of Business at the University of Cincinnati.

Hosack, B., Hall, D., Paradice, D., \& Courtney, J. (2012). A look toward the future: decision support systems research is alive and well. Journal of the Association for Information Systems, 13(4). https://doi.org/10.17705/1jais.00297

Laudon, C. K., \& Laudon, P. J. (2002). Management Information Systems Managing the Digital Firm. 7th Edition: N.Y: Prentice - Hall International. Inc.

Lliyan, W. (2015). Incorporating Gamification into Performance Management to Drive Employees' Engagement Case Study- Mercy Corp, Unpublished Master Thesis, the Islamic University, and Gaza.

Louden, C., \& Louden, J. (2006). Management Information Systems: Managing the Digital Firm, Global Edition. Thirteen Editions. Nwegersy: Prentice- Hall International.

Markgraf, M. (2013). Characteristics of Good Management Information System. Texas: Houston Chronicle.

Noe, R., Hollen-back, J., Gerhart, B., \& Wright, P. (2018). Fundamental Human Resource Management. Seventh Edition. New York: McGraw-Hill Companies Inc.

O’Connor, R. (2006). Organizational Information Systems. New Jersey: Prentice-Hall. Inc.

Sahu, R., \& Jena, L. (2016). Performance Management System as a Predictor of Organizational Effectiveness: Insights from Indian Manufacturing Industries. Jindal Journal of Business Research, (3), No. (1+2). https://doi.org/10.1177/2278682115627214 


\section{Macrothink}

International Journal of Human Resource Studies

ISSN 2162-3058 2019, Vol. 9, No. 3

Saud, S. (2017). Knowledge sharing and performance in health sectors in the kingdom of Bahrain. Unpublished Thesis, Business Faculty, AL Ahlia University, Al Bahrain.

Sekaran, U., \& Bouge. (2012).Research methods for business a skill building approach. 5th ed. Wiley.

Stair, M., Ralph, A., \& Reynolds, W. (2013). Principles of Information Systems: A Managerial Approach. 6th Edition, Canada: Thomson Course Technology.

Tawaaf, A. K. (2010). Management information systems and decision making. Imran: Publications of the Yemeni University of Amran.

Torrington, D., Hall, L., \& Taylor, A. (2014). Human Resource Management. Nine Editions. UK: Pearson Education Limited.

Zheng, E. (2013). Ethical and Social Issues in Information Systems. Retrieved November 29, 2018. http://ocmis.blogspot.com/ethical-and-social-issues-in.html

\section{Copyright Disclaimer}

Copyright for this article is retained by the author(s), with first publication rights granted to the journal.

This is an open-access article distributed under the terms and conditions of the Creative Commons Attribution license (http://creativecommons.org/licenses/by/4.0/). 